Article

\title{
Boundary-Spanning Search for Knowledge, Knowledge Reconstruction and the Sustainable Innovation Ability of Agricultural Enterprises: A Chinese Perspective
}

\author{
Kaifeng Duan ${ }^{1}$, Changcheng Zhang ${ }^{1,2, * \mathbb{C}}$, Junqiang $\mathrm{Li}^{1, *}$, Rui Zhang ${ }^{3}$ and Yanwei Zhang ${ }^{4} \mathbb{D}$ \\ 1 School of Economics and Management, Tongji University, Shanghai 200092, China; \\ kefee920729@tongji.edu.cn \\ 2 Business School, Jinggangshan University, Ji'an 343009, China \\ 3 Land Satellite Remote Sensing Application Center, Ministry of Natural Resources, Beijing 100048, China; \\ ruizh581@163.com \\ 4 School of Tourism and Urban Management, Jiangxi University of Finance and Economics, \\ Nanchang 330032, China; bsonyan@126.com \\ * Correspondence: 1410371@tongji.edu.cn (C.Z.); ljq@tongji.edu.cn (J.L.)
}

Received: 9 January 2020; Accepted: 6 February 2020; Published: 9 February 2020

check for updates

\begin{abstract}
Boundary-spanning search for knowledge is an effective way for enterprises to acquire heterogeneous knowledge, and is also an important pre-stage to realize effective knowledge reconstruction. Based on the boundary-spanning search for knowledge theory, this paper studies the relationship between boundary-spanning search for knowledge and the sustainable innovation ability of agricultural enterprises considering the influence of organizational knowledge reconstruction, from a Chinese perspective. A questionnaire survey on agricultural enterprises mainly from Southeast China is conducted, and the hierarchical regression analysis method is utilized to verify five research hypotheses. The results mainly show that (1) boundary-spanning search for technology knowledge (BSSTK) and boundary-spanning search for market knowledge (BSSMK) both have a significant positive impact on the sustainable innovation ability of an agricultural enterprise; (2) organizational knowledge reconstruction plays a partial intermediary role between boundary-spanning search for knowledge (including BSSTK and BSSMK) and the sustainable innovation ability of an agricultural enterprise. From the perspective of boundary-spanning search for knowledge, this paper provides theoretical support for the promotion of sustainable innovation of an agricultural enterprise, which contributes to improving the economic sustainability of agriculture to some extent.
\end{abstract}

Keywords: boundary-spanning search; knowledge reconstruction; sustainable innovation; agricultural enterprise; agricultural sustainability

\section{Introduction}

In the light of globalization, the change of the market environment and technology environment is accelerated. If the innovation of an enterprise is not sustainable, its advantage will be hard to maintain [1]. Competitiveness plays an important role in an agricultural enterprise [2], hence, the agricultural enterprise needs sustainable innovation to better survive and develop in the competitive global market. As one type of enterprise engages in agriculture related production and operation activities, traditional agricultural enterprise solely relying on the closed innovation of internal knowledge reserve is easy to fall into the "path dependence" [3] and "capability trap" [4], leading to the failure of enterprise sustainable innovation. Previous research on sustainable innovation of an agricultural enterprise 
mainly focuses on the aspects of industrial capital, government support policy, corporate culture and strategic orientation, and internal technical basis, such as the relationship between capital type and enterprise innovation [5], impact of government support on leading enterprises [6], influence of strategic orientation and institutional culture on enterprise innovation [7], and influence of the internal knowledge and technological basis of an agricultural enterprise on innovation [8]. Some scholars also emphasize the importance of an innovation environment. For instance, Uvarova and Vitola point out that an innovation environment has the greatest impact on the sustainable innovation of small and medium sized agricultural enterprises [9]. However, few scholars discuss the influence of external heterogeneous knowledge elements on sustainable innovation from the external perspective of an agricultural enterprise. Research on the sustainable innovation ability of an agricultural enterprise combining the external knowledge acquisition with the internal knowledge management is lacking [10]. Innovation is inseparable from heterogeneous and novel external knowledge and also inseparable from efficient internal knowledge management [11]. Therefore, it is increasingly necessary for an agricultural enterprise to take the initiative to acquire external heterogeneous and novel knowledge across organizational boundaries and improve the efficiency of internal knowledge management, so as to enhance the sustainable innovation ability.

Boundary-spanning search for knowledge is an important way to acquire external knowledge and creativity to enhance the competitive advantage of an enterprise [12]. Therefore, it is regarded by scholars as not only a way to solve the problem of internal innovation of an enterprise, but also a way to learn from other sectors. Organizational knowledge reconstruction is a way of knowledge management, which emphasizes the creation of an open learning structure for an enterprise to constantly reorganize knowledge resources to create new products [13]. Due to the regional embeddedness and relatively closed characteristics, the sustainable innovation ability of an agricultural enterprise is generally weak, which seriously hinders high quality development of the agricultural enterprise in the era of the Internet economy. Under this situation, it's imperative for an agricultural enterprise to cross the organizational boundary, expand the sources of innovative knowledge, and carry out effective organizational knowledge reconstruction, so as to promote sustainable innovation. Currently, the influence mechanism between boundary-spanning search for knowledge, knowledge reconstruction and the sustainable innovation ability of an agricultural enterprise still remains to be tested. Based on the boundary-spanning search for knowledge theory, considering the intermediary function of organizational knowledge reconstruction, this paper discusses the relationship between boundary-spanning search for knowledge and the sustainable innovation ability of an agricultural enterprise from a Chinese perspective by taking account of two knowledge types (i.e., market knowledge and technology knowledge), which have great influence on enterprise sustainable innovation. We conducted a questionnaire survey on agricultural enterprises mainly from Southeast China and utilized the hierarchical regression analysis method [14] to verify five research hypotheses. China is a large agricultural country, but there is still a big gap in the innovation ability of Chinese agricultural enterprises compared with that of many other international agricultural enterprises. Hence studying the sustainable innovation ability of agricultural enterprises from a Chinese perspective seems to be more meaningful. The novel contribution of this paper is to test a theoretical conceptual model to understand the influence mechanism between boundary-spanning search for knowledge, knowledge reconstruction and the sustainable innovation ability of an agricultural enterprise within an empirical study framework, by applying the theoretical lenses of the boundary-spanning search for knowledge theory to agricultural enterprises. The research findings of this paper can provide theoretical support for the promotion of sustainable innovation of an agricultural enterprise, and can contribute to improving the economic sustainability of agriculture to some extent.

\section{Theoretical Basis and Research Hypothesis}

This paper chooses the agricultural enterprise as the research object. An agricultural enterprise refers to the enterprise engaged in agriculture related production and operation activities, hence it 
has all the general characteristics of a general enterprise, and the theoretical support suitable for a general enterprise is also suitable for an agricultural enterprise. Based on the boundary-spanning search for knowledge theory and the review on existing relative literature, this paper posits five hypotheses and constructs a conceptual model of the effect of boundary-spanning search for knowledge on the sustainable innovation ability of an agricultural enterprise, from a general enterprise to an agricultural enterprise.

\subsection{Boundary-Spanning Search for Knowledge and the Sustainable Innovation Ability of an Agricultural Enterprise}

Sustainable innovation is an important index to measure the competitiveness of an enterprise in the market. It means that the enterprise can continuously launch and implement new innovation projects, and can continuously realize economic benefits [15]. There are many influencing factors on the sustainable innovation ability of an enterprise, which can be summarized into two categories. One category involves the internal factors of the enterprise, including the inertia effect of "winners more successful", knowledge accumulation and dynamic scale effect, and the cost effect of R \& D investment [16]. Another category involves the external factors of the enterprise, including industry characteristics, market characteristics, and external relations of the enterprise [17].

According to the boundary-spanning search for knowledge theory, boundary-spanning search for knowledge is the key bond linking these internal and external factors. The boundary-spanning search for knowledge theory stems from the idea of "organizational search" proposed by Cyert and March in 1963 [18]. Organizational search generally refers to the search activities conducted when an organization crosses a certain boundary. Rosenkopf and Nerkar took the lead in introducing boundary-spanning search into the field of strategic management [19]. At present, the academic community has formed a consistent understanding of boundary-spanning search and generally accepted the view that boundary-spanning search is a problem-solving approach and an organizational learning way [20]. In recent years, boundary-spanning search for knowledge has become the third way to enhance the competitive advantage of an organization following the organizational internal $R$ \& $D$ and organizational external acquisitions [21,22]. Based on the boundary-spanning search for knowledge theory, heterogeneous knowledge is an important resource for an organization to innovate continuously and obtain a competitive advantage. The acquisition of external heterogeneous knowledge can make up for the lack of local innovation knowledge of an enterprise. Boundary-spanning search for knowledge is an important way for organizations to acquire external heterogeneous and novel knowledge [19]. In essence, it is a way of organizational learning and a self-renewal process, and can be considered as an attempt of an enterprise to discover new knowledge with new ideas or ways [23]. Through boundary-spanning search for knowledge, an enterprise can continuously absorb new knowledge elements from the outside, update the existing knowledge base, and effectively adapt to the dynamic changes of external environment.

Nowadays, from the perspective of the knowledge type, scholars generally divide boundaryspanning search for knowledge into two dimensions: boundary-spanning search for technology knowledge (BSSTK) and boundary-spanning search for market knowledge (BSSMK) [24]. As the division of labor in the value chain of the agricultural industry becomes more and more clear, it is difficult for any single agricultural enterprise to complete its innovation activities only relying on its own technology. Under this situation, the boundary-spanning search behavior targeting external knowledge becomes a powerful guarantee to improve the innovation ability and maintain dynamic competitiveness of an agricultural enterprise [25]. Through BSSTK, an agricultural enterprise can not only obtain differential technical elements and innovative ideas, but can also break through the original technical limitations and create potential solutions for technical problems in a more direct way via the combination of internal and external knowledge. This may result in a breakthrough of technology innovation [26], and is beneficial to the cultivation of a sustainable innovation ability of an agricultural enterprise. BSSMK is an extensive search for relevant information of customer demand 
and preference. The relationship between the enterprise and customers should be paid attention to ain the process of operation and management of an agricultural enterprise [27]. BSSMK not only pays attention to the actual needs of existing customers, but also pays attention to the potential needs of the customers. On the one hand, BSSMK makes it possible for the enterprise to fully understand market dynamics, clarify current needs of the customers, which is helpful for the enterprise to gain insight into the potential demand that has not been met in the market, and take the lead in original product development [28]. For example, in Hungary, small and medium sized agricultural enterprises usually use public advisory service provided by a rural consultant network or interbank organizations to obtain information about current marketing trends and prices [29]. On the other hand, BSSMK enables the enterprise to find potential emerging markets and marginal customer groups, which is helpful in providing a stable customer group for the development of new products. BSSMK involves the absorption and utilization of knowledge beyond the organization's existing market knowledge boundary, which provides the enterprise with new heterogeneous information about the customers and competitors as a supplement of their existing skills, knowledge, and experience [30]. This is beneficial for the enterprise in order to conduct innovation research and development according to the market demand, and improve the sustainability of innovation output of the enterprise.

Accordingly, this paper posits the following hypotheses:

Hypothesis 1. BSSTK positively correlates with the sustainable innovation ability of an agricultural enterprise.

Hypothesis 2. BSSMK positively correlates with the sustainable innovation ability of an agricultural enterprise.

\subsection{Boundary-Spanning Search for Knowledge and Knowledge Reconstruction}

The essence of knowledge reconstruction lies in the knowledge exchange under the premise of knowledge diversity and heterogeneity [31]. The stronger the diversity and heterogeneity of knowledge, the more likely the reconstruction behavior based on knowledge exchange is to occur. Knowledge reconstruction is an important way to make use of organizational knowledge, including two dimensions of expanding knowledge reconstruction and deepening knowledge reconstruction [32]. Expanding knowledge reconstruction refers to the new integration of enterprise knowledge in the original field and new creation of enterprise knowledge in a new field, while deepening knowledge reconstruction means the structural change of knowledge elements, which is the combination of the original knowledge and new knowledge of an enterprise. The embeddability, diversity, and novelty of boundary-spanning knowledge are the source of enterprise innovation [33]. From a knowledge source perspective, the effective acquisition of external knowledge by boundary-spanning search increases the elements for enterprise knowledge reconstruction and enhances the potential of enterprise knowledge reconstruction [34]. BSSTK is beneficial to the interaction and exchange of internal and external technical knowledge of an enterprise. The heterogeneity of external technical knowledge is often an important trigger factor to stimulate the growth of internal knowledge of an organization, which has an important promoting effect on knowledge reconstruction of an enterprise. BSSMK can increase the opportunity of an enterprise to investigate the external environment from multiple angles, improving the ability of an enterprise to perceive market changes, which is conductive to market-oriented knowledge reconstruction, improving product quality, increasing product functions, and reducing product costs.

Accordingly, this paper posits the following hypotheses:

Hypothesis 3. BSSTK positively correlates with knowledge reconstruction of an agricultural enterprise.

Hypothesis 4. BSSMK positively correlates with knowledge reconstruction of an agricultural enterprise. 


\subsection{Knowledge Reconstruction and the Sustainable Innovation Ability of an Agricultural Enterprise}

Knowledge reconstruction solves the problems of boundary-spanning knowledge management of an organization, focusing on the boundary-spanning thinking and striving to achieve the unity of organizational knowledge acquisition and organizational innovation targets at a higher level. In an open innovation environment, innovation is regarded as a process of reorganizing knowledge [35]. The behavior of boundary-spanning search for knowledge of an enterprise can change the structure of organizational knowledge and bring diverse and heterogeneous external knowledge into the innovative activities of the enterprise. Specifically, BSSTK helps to change the structure of the enterprise's technical knowledge, and a large number of technical innovation elements can be brought into the enterprise innovation activities. BSSMK helps to change the application environment of enterprise knowledge and ability, and brings more market information elements to help the enterprise better develop in the market. These external elements aiming at innovation need to be deconstructed, reconstructed, and coupled within the enterprise to realize the renewal of organizational knowledge. How to realize the integration of new and old organizational knowledge is an important issue related to the sustainable innovation of an enterprise. Effective boundary-spanning knowledge management is considered to be a key factor in creating competitive advantage [36]. Through the theoretical study on industry, university, and research institute, it is found that there is often a gap in the application and creation between the new added knowledge from the outside and knowledge needed by the organization, and further knowledge reconstruction is needed to produce its due intermediate effect [37]. Knowledge reconstruction can make knowledge easier to be understood and applied, help to find the defect of knowledge and improve the application efficiency of knowledge. When the external knowledge (i.e., knowledge flow) and the existing knowledge (i.e., knowledge stock) of an organization are difficult to be fused due to diversity and heterogeneity of knowledge, knowledge reconstruction is needed to be processed, so as to promote the integration of the knowledge flow and stock. In this way, the knowledge resource can be finally changed into an actual competitive advantage and the goal of improving the sustainable innovation ability of an enterprise can be achieved.

Accordingly, this paper posits the following hypothesis:

Hypothesis 5. Knowledge reconstruction positively correlates with the sustainable innovation ability of an agricultural enterprise and plays an intermediary role between boundary-spanning search for knowledge and the sustainable innovation ability of an agricultural enterprise.

In summary, a conceptual model of the effect of boundary-spanning search for knowledge on the sustainable innovation ability of an agricultural enterprise is established as shown in Figure 1.

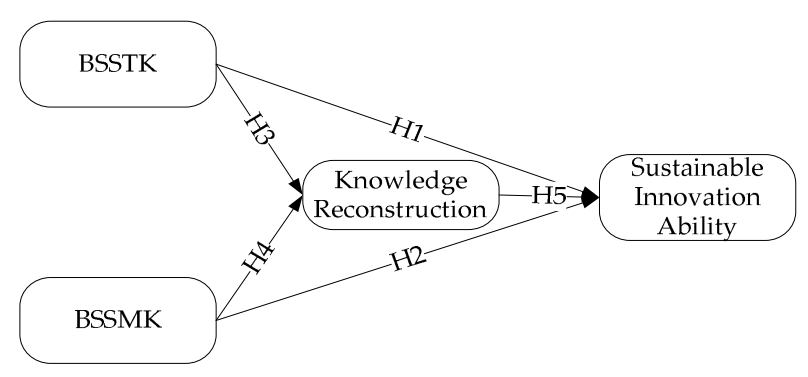

Figure 1. Conceptual model of the effect of boundary-spanning search for knowledge on the sustainable innovation ability of an agricultural enterprise. 


\section{Research Design}

\subsection{Research Sample and Variable Measurement}

The studied enterprises are mainly from Southeast China (including agricultural enterprises from Jiangsu Province, Anhui Province, Shanghai, Zhejiang Province, Jiangxi Province, Fujian Province, and Guangdong Province). This is because the southeastern region of China is the earliest area for opening up new markets and innovative development. Compared with other areas, the agriculture in this area is more developed, and the development of agricultural enterprises in this area is more mature. Therefore, agricultural enterprises from Southeast China are more representative. During a one-year period from March 2018 to March 2019, a total number of 610 questionnaires were released through field visit, WeChat and e-mail, and 308 questionnaires were actually recovered. After eliminating some incomplete and invalid questionnaires, the rest of 259 effective questionnaires (the effective recovery rate of the questionnaires was $42.5 \%$ ) were used to conduct further analysis. The basic information of the sample enterprises is shown in Table 1.

Table 1. Basic information of the sample enterprises.

\begin{tabular}{|c|c|c|c|c|c|}
\hline Enterprise Age & Number & Proportion (\%) & Enterprise Scale & Number & Proportion (\%) \\
\hline Below 2 years & 4 & 1.5 & Below 50 employees & 27 & 10.4 \\
\hline $2-5$ years & 11 & 4.2 & 51-100 employees & 145 & 56.0 \\
\hline $6-10$ years & 40 & 15.4 & 101-500 employees & 41 & 15.8 \\
\hline $11-15$ years & 53 & 20.5 & 501-1000 employees & 25 & 9.7 \\
\hline Above 15 years & 151 & 58.3 & Above 1000 employees & 21 & 8.1 \\
\hline $\begin{array}{c}\text { Service } \\
\text { Duration of the } \\
\text { Respondents }\end{array}$ & Number & Proportion (\%) & $\begin{array}{l}\text { Position of the } \\
\text { Respondents }\end{array}$ & Number & Proportion (\%) \\
\hline $\begin{array}{c}\text { Below } 2 \text { years } \\
2-5 \text { years }\end{array}$ & $\begin{array}{l}15 \\
52\end{array}$ & $\begin{array}{c}5.8 \\
20.1\end{array}$ & Senior Manager & 212 & 81.9 \\
\hline $\begin{array}{c}6-10 \text { years } \\
\text { Above } 10 \text { years }\end{array}$ & $\begin{array}{c}120 \\
72\end{array}$ & $\begin{array}{l}46.3 \\
27.8\end{array}$ & Middle Manager & 47 & 18.1 \\
\hline
\end{tabular}

This paper conducts an empirical study by means of a questionnaire survey. In order to ensure the quality of the survey, only middle and senior managers were invited to fill out the questionnaires. In the process of data collection, to ensure the reliability and validity of the variables, the scales of the variables involved in this paper are all from existing mature studies, which have been widely proved to have high internal consistency and effectiveness. Following the basic procedures of a questionnaire survey, professionals and academic scholars in relevant fields were consulted before the formation of the questionnaire. According to the actual needs of this study, the expression form of some statements was slightly changed without changing the actual content of the scale, and a preliminary questionnaire was formed. In order for the questionnaire to meet the basic requirements of scientific research, referring to the research procedures of previous similar research, 30 agricultural enterprises in Shanghai were selected for pre-survey before the formal questionnaire survey. According to the feedback of the pre-survey, relevant experts in the field of this study were invited to revise it again, and finally to form the formal questionnaire of this paper as shown in Table 2. 
Table 2. Measurements, reliability, and validity of the constructs.

\begin{tabular}{|c|c|c|c|c|c|c|}
\hline Constructs. & Item Content & Factor Loading & $\alpha$ Coefficient & KMO & CR & AVE \\
\hline \multirow{4}{*}{ BSSTK } & (1) We are well aware of the technological development of our industry. & 0.872 & \multirow{4}{*}{0.889} & \multirow{4}{*}{0.835} & \multirow{4}{*}{0.923} & \multirow{4}{*}{0.751} \\
\hline & (2) We collect information about all industries that use the same technology as we do. & 0.854 & & & & \\
\hline & (3) We are always concerned about industry information that is technically relevant to us. & 0.882 & & & & \\
\hline & (4) We closely monitor the technical progress of the products and processes of the suppliers. & 0.858 & & & & \\
\hline \multirow{4}{*}{ BSSMK } & (1) We pay close attention to the information of companies that target our customers. & 0.806 & \multirow{4}{*}{0.821} & \multirow{4}{*}{0.782} & \multirow{4}{*}{0.882} & \multirow{4}{*}{0.652} \\
\hline & (2) We understand the changes in customer preferences for products. & 0.701 & & & & \\
\hline & $\begin{array}{l}\text { (3) We pay close attention to industries that provide products which are completely different } \\
\text { from those of our company but meet the same customer needs. }\end{array}$ & 0.855 & & & & \\
\hline & $\begin{array}{l}\text { (4) We pay close attention to the activities of companies that provide complementary products } \\
\text { of our company. }\end{array}$ & 0.857 & & & & \\
\hline \multirow{7}{*}{$\begin{array}{l}\text { Knowledge } \\
\text { Reconstruction }\end{array}$} & (1) Our company has a new concept of innovation. & 0.746 & \multirow{7}{*}{0.849} & \multirow{7}{*}{0.847} & \multirow{7}{*}{0.887} & \multirow{7}{*}{0.530} \\
\hline & (2) Our company has a new understanding of market opportunities. & 0.641 & & & & \\
\hline & (3) The innovative thought and innovative knowledge of our company are very novel. & 0.707 & & & & \\
\hline & (4) The new products of our company embody novel technologies and functions. & 0.812 & & & & \\
\hline & (5) Our company can view market opportunities from multiple perspectives. & 0.799 & & & & \\
\hline & (6) The innovative ideas and knowledge of our company come from different fields. & 0.728 & & & & \\
\hline & (7) The products of our company integrate technical knowledge in a wide range of fields. & 0.642 & & & & \\
\hline \multirow{5}{*}{$\begin{array}{c}\text { Sustainable } \\
\text { Innovation } \\
\text { Ability }\end{array}$} & (1) Our company is able to launch new products or services more quickly than its competitors. & 0.856 & \multirow{5}{*}{0.877} & \multirow{5}{*}{0.868} & \multirow{5}{*}{0.911} & \multirow{5}{*}{0.671} \\
\hline & (2) Our company is able to open up new markets more quickly than its competitors. & 0.786 & & & & \\
\hline & (3) Our company is able to enter mature markets earlier than its competitors. & 0.807 & & & & \\
\hline & $\begin{array}{l}\text { (4) Our company can better control the supply sources and channels of raw materials and } \\
\text { outsourcing products, compared with its competitors. }\end{array}$ & 0.812 & & & & \\
\hline & $\begin{array}{l}\text { (5) Our company attaches more importance to cooperative innovation or R \& D investment, } \\
\text { compared with its competitors. }\end{array}$ & 0.832 & & & & \\
\hline
\end{tabular}


The dependent variable (i.e., sustainable innovation ability of an agricultural enterprise) is measured with five items, borrowing the multi-index comparison method of Zhang and Ren [38]. The independent variable (i.e., boundary-spanning search for knowledge of an agricultural enterprise) is measured in terms of BSSTK and BSSMK, consisting of four items respectively, referring to the scales of Sidhu et al. [24] and Zhu et al. [39]. The intermediating variable (i.e., knowledge reconstruction) is measured with seven items referring to the study of Ye et al. [32]. The questionnaire is designed in form of a seven-point Likert scale $(1=$ no match, while $7=$ complete match; increasing from low to high) to measure the matching degree between the questionnaire items and the situation of the enterprises. In addition, $\mathrm{R} \& \mathrm{D}$ investment [40], enterprise scale [41,42], and enterprise age [43] are selected as control variables. Among them, the R \& D investment variable is measured by the proportion of $\mathrm{R} \& \mathrm{D}$ investment in sales revenue of the enterprise (" 1 " represents that the proportion is "below 1\%", " 2 " represents " $1 \%-3 \%$ ", “ 3 " represents " $3 \%-5 \%$ ", " 4 " represents " $5 \%-8 \%$ ", and " 5 " represents "above $8 \%$ "). The enterprise scale variable is measured by the number of employees of the enterprise (" 1 " represents that the enterprise scale is "less than 50 employees", " 2 " represents “50-100 employees", “3" represents "101-500 employees", “4” represents "501-1000 employees" and " 5 " represents "more than 1000 employees"). The enterprise age variable is measured by the number of years since the establishment of the enterprise (" 1 " represents that the enterprise age is "less than 2 years", “2" represents "2-5 years", “3" represents "6-10 years", " 4 " represents "11-15 years" and “5” represents "more than 15 years").

\subsection{Reliability and Validity Test}

In this paper, the SPSS and AMOS statistical software were used for data analysis. The Cronbach $\alpha$ coefficient was used to test the internal consistency of the questionnaire. As shown in Table 2, it can be found that the Cronbach $\alpha$ coefficients of all variables was greater than 0.8 , indicating that the internal consistency of the questionnaire has passed the test. Subsequently, we conducted the KMO analysis and found that the KMO values of all the items were greater than 0.7 , indicating that the design of variables in this study is scientific and reasonable. Through factor analysis, it was found that the factor loading of each item was within the normal range of $0.5-0.95$, the combined reliability (CR) values of the items were all greater than 0.6 , and the average variance extraction (AVE) values were all higher than 0.5 , indicating that the reliability and aggregation validity of the questionnaire were good. The AMOS software was used to test the fitness of the model, the results showed that (1) $x^{2}=301.663$, $D f=164, x^{2} / D f=1.84$ (less than the threshold value 2); (2) CFI $=0.951, \mathrm{TLI}=0.944, \mathrm{IFI}=0.952$, which are all greater than the threshold value 0.9; (3) RMSEA $=0.057$ (less than the threshold value 0.08). These results indicated that the variables had a good structural validity and distinguishing validity, and the fitness of the model was good. Moreover, the homology error test was carried out by the Harman factor test, and the results confirmed that there were several common factors whose characteristic roots were greater than 1 ; the total variation interpretation amount was $65.123 \%$, and the first principal component was $46.177 \%$ (the KMO value was 0.941 , Bartlett- $p$ value was 0.000 ), which did not exceed the critical value of $50 \%$, meaning that the homology error test had been passed.

\section{Research Results}

\subsection{Descriptive Statistics and Correlation Analysis of Variables}

The average value, standard deviation, and correlation coefficient of each variable are shown in Table 3. The correlation coefficient of each variable is less than 0.7 , and the variance inflation factor (VIF) values corresponding to all independent variables were all less than 10, which implying the multiple collinearity between variables can be ignored. From the research results, it can be seen that (1) there is a positive and significant correlation between boundary-spanning search for knowledge (including BSSTK, the correlation coefficient $\mathrm{r}=0.649, p<0.01$; and BSSMK, the correlation coefficient $\mathrm{r}=0.662$, $p<0.01$ ) and sustainable innovation ability; (2) there is a positive and significant correlation between 
boundary-spanning search for knowledge (including BSSTK, the correlation coefficient $\mathrm{r}=0.575$, $p<0.01$; and BSSMK, the correlation coefficient $\mathrm{r}=0.641, p<0.01$ ) and knowledge reconstruction; (3) there is a positive and significant correlation between knowledge reconstruction (the correlation coefficient $r=0.663, p<0.01$ ) and sustainable innovation ability. This provides preliminary support for the research hypotheses.

Table 3. Means, standard deviations (S.D.), and correlation coefficients of variables.

\begin{tabular}{|c|c|c|c|c|c|c|c|c|c|}
\hline Variables & Means & S.D. & 1 & 2 & 3 & 4 & 5 & 6 & 7 \\
\hline 2. Enterprise Scale & 2.49 & 1.069 & -0.088 & 1 & & & & & \\
\hline 4. BSSTK & 5.479 & 0.865 & $0.147^{*}$ & -0.014 & $0.384^{* *}$ & 1 & & & \\
\hline 5. BSSMK & 5.632 & 0.841 & $0.159 *$ & $-0.141^{*}$ & $0.332 * *$ & $0.594^{* *}$ & 1 & & \\
\hline 6. Knowledge Reconstruction & 5.564 & 0.817 & $0.126^{*}$ & $-0.138 *$ & $0.321 * *$ & $0.575^{* *}$ & $0.641^{* *}$ & 1 & \\
\hline
\end{tabular}

Note: $\mathrm{N}=259,{ }^{* *}$ denotes $p<0.01,{ }^{*}$ denotes $p<0.05$.

\subsection{Hypothesis Test}

The hypothesis of this paper is tested by the layer-by-layer regression analysis [42], and the test results are shown in Table 4. Model 1 (M1) is the basic model only to test the effect of the control variables on sustainable innovation ability, which is tested to be significant $(p<0.001)$. On the basis of M1, we expand this model to Model 2 (M2) by adding the independent variable, i.e., boundary-spanning search for knowledge (including BSSTK and BSSMK). M2 is also tested to be significant $(p<0.001)$. It can be seen from Table 4 that, from M1 to M2, Adj- $R^{2}$ increases from 0.158 to 0.540 , indicating that the explanatory power of the model is enhanced. It can be found that BSSTK $(\beta=0.372, p<0.001)$ and BSSMK $(\beta=0.404, p<0.001)$ are both positively correlated with sustainable innovation ability, proving that Hypothesis 1 and Hypothesis 2 hold.

Table 4. Layer-by-layer regression analysis results.

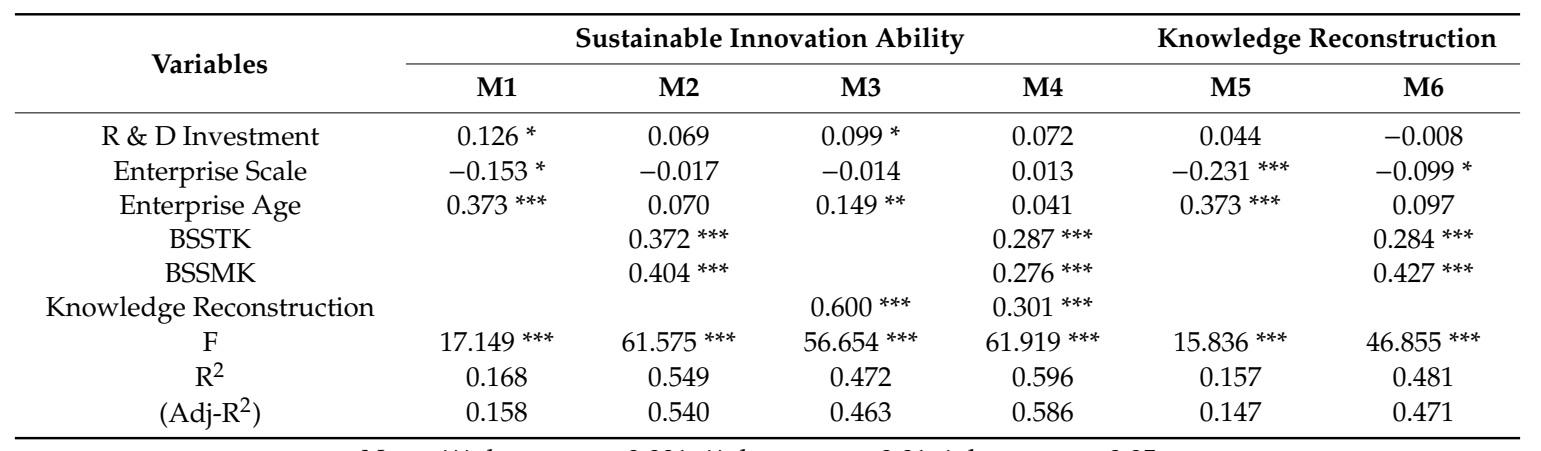

Note: ${ }^{* * *}$ denotes $p<0.001,{ }^{* *}$ denotes $p<0.01,{ }^{*}$ denotes $p<0.05$.

According to Baron and Kenny's mediation test method [44], the significant relationship between the independent variables and dependent variables is proved. Model 5 (M5) is the basic model to test the relationship between the control variables and intermediate variable (i.e., knowledge reconstruction). On the basis of M5, we expand this model to Model 6 (M6) by adding the independent variables (i.e., BSSTK and BSSMK) to test the relationship between the independent variables and knowledge reconstruction. The models are both tested to be significant. From M5 to M6, Adj- $R^{2}$ increases from 0.147 to 0.471 , indicating that the explanatory power of the model is enhanced. It can be found that BSSTK $(\beta=0.284, p<0.001)$ and BSSMK $(\beta=0.427, p<0.001)$ are both positively correlated with knowledge reconstruction, proving that Hypothesis 3 and Hypothesis 4 hold. Model 3 (M3) is the model to test the relationship between the intermediate variable and dependent variable. It can be found that knowledge reconstruction $(\beta=0.600, p<0.001)$ is positively correlated with sustainable 
innovation ability. Model 4 (M4) is established on the basis of M2 by adding the intermediate variable (i.e., knowledge reconstruction) to test the intermediate effect of knowledge reconstruction. M4 is also tested to be significant. Furthermore, from M2 to M4, Adj- $R^{2}$ increases from 0.540 to 0.586 , indicating that the explanatory power of the model is enhanced. This result proves that Hypothesis 5 holds. Moreover, from M2 to M4, the correlation coefficient between BSSTK and the sustainable innovation ability has reduced from $(\beta=0.372, p<0.001)$ to $(\beta=0.287, p<0.001)$, and the correlation coefficient between BSSMK and the sustainable innovation ability has reduced from $(\beta=0.404, p<0.001)$ to ( $\beta=0.276, p<0.001)$, further verifying that the knowledge reconstruction variable plays a partial intermediary role between boundary-spanning search for knowledge and the sustainable innovation ability of an agricultural enterprise.

\section{Discussions and Conclusions}

In an empirical study framework, this paper probes deeply into the influence mechanism between boundary-spanning search for knowledge, knowledge reconstruction, and the sustainable innovation ability of agricultural enterprises from a Chinese perspective. We conducted a questionnaire survey on agricultural enterprises mainly from Southeast China and utilized the hierarchical regression analysis method to verify five research hypotheses. The research results prove that (1) BSSTK and BSSMK both have a significant positive impact on the sustainable innovation ability of an agricultural enterprise; (2) BSSTK and BSSMK both have a significant positive impact on knowledge reconstruction of an agricultural enterprise; (3) knowledge reconstruction has a significant positive impact on the sustainable innovation ability of an agricultural enterprise, and plays a partial intermediary role between boundary-spanning search for knowledge (including BSSTK and BSSMK) and the sustainable innovation ability of an agricultural enterprise.

Compared with previous studies around the sustainable innovation of agricultural enterprises, this paper is the very first attempt considering the influence of boundary-spanning search for knowledge and knowledge reconstruction. The contribution of this paper can be summarized in two aspects. First, the boundary-spanning search for knowledge theory is applied to the innovation and development practice of agricultural enterprises, which expands the application scope of the boundary-spanning search for knowledge theory. In the era of the Internet economy, the lack of knowledge innovation within an agricultural enterprise is an important reason to hinder the sustainable development of the enterprise. Through boundary-spanning search for knowledge, an agricultural enterprise can acquire external novel and heterogeneous technology knowledge and market knowledge, which is helpful to improve the sustainable innovation ability of the enterprise. This is also conductive to improving economic sustainability of agriculture to some extent. Both BSSTK and BSSMK play an important role in promoting the sustainable innovation of an agricultural enterprise. Therefore, managers of agricultural enterprises should attach great importance to the role of boundary-spanning search for knowledge, and strengthen the cultivation of boundary-spanning search for knowledge proficiency. Second, the relationship between boundary-spanning search for knowledge, knowledge reconstruction, and the sustainable innovation ability of agricultural enterprises is clarified. The conclusion that a boundary-spanning knowledge resource can enhance the sustainable innovation ability of an enterprise in the open innovation environment is verified [45] from the perspective of agricultural enterprises. Based on existing research, the concept of organizational knowledge reconstruction is introduced into the innovation research of agricultural enterprises, and its intermediate role in the mechanism of boundary-spanning search for knowledge enhancing sustainable innovation ability of agricultural enterprises is verified by empirical evidence. In the Internet era, with its rapid change in market environment and technology renewal, the timeliness of knowledge is getting stronger and stronger. Through effective organizational knowledge reconstruction, the external knowledge acquired by boundary-spanning search can better contribute to the cultivation of the sustainable innovation ability of agricultural enterprises. These research findings are consistent with Cohen and Levinthal's emphasis that "enterprises must reconstruct knowledge in their knowledge applications to meet the changing 
needs of the market" [46], and enrich the process theory of transforming boundary-spanning knowledge into enterprise sustainable innovation ability. For the managers of agricultural enterprises, in addition to paying attention to the absorption of external knowledge, they also need to improve the efficiency of knowledge reconstruction to adapt to the rapidly changing external market environment. Therefore, at the practical level, the top-level authorities of agricultural enterprises can make effective regulations and policies to promote the efficiency and quality of boundary-spanning search for knowledge and knowledge reconstruction.

Some research still remains to be done in the future due to some limitations in this paper. Firstly, although the effect of both BSSTK and BSSMK on the sustainable innovation ability of an agricultural enterprise is considered in this paper, what kind of combination should be maintained between BSSTK and BSSMK to achieve the optimal state of sustainable innovation of an agricultural enterprise still remains to be answered in the future. Secondly, only the intermediate role of knowledge reconstruction in the process of boundary-spanning innovation of agricultural enterprises is examined in this paper, while some other factors (e.g., organization structure), which may also have intermediate impact on the sustainable innovation ability of an agricultural enterprise, have not yet been explored herein. Thirdly, this paper only explores the uni-directional relationships between boundary-spanning search for knowledge, knowledge reconstruction, and the sustainable innovation ability of agricultural enterprises. However, in reality, there may be complex bi-directional relationships between them. Exploring the impact of knowledge reconstruction and the sustainable innovation ability on boundary-spanning search for knowledge may add objectivity to the findings as another fertile ground for future study.

Author Contributions: K.D. and C.Z. conceived and designed the study; C.Z. completed the paper in English and K.D. revised it critically for important intellectual content; J.L. gave many good research advices and revised the manuscript; R.Z. and Y.Z. made a comprehensive English revision. All authors have read and agreed to the published version of the manuscript.

Funding: This research is supported by the National Social Science Foundation of China (19BGL274).

Acknowledgments: The authors wish to thank the anonymous reviewers, whose insightful comments and helpful suggestions significantly contributed to improving this paper.

Conflicts of Interest: The authors declare no conflict of interest.

\section{References}

1. Antonelli, C.; Crespi, F.; Scellato, G. Internal and external factors in innovation persistence. Econ. Innov. New Technol. 2013, 22, 256-280. [CrossRef]

2. Dung, N.T.; Hanh, P.T.M.; Phuong, P.T. Competitiveness of vietnamese agricultural enterprises in the globalization. Asian J. Sci. Technol. 2018, 9, 8992-8997.

3. Liebowitz, S.J.; Margolis, S.E. Path dependence, lock-in, and history. J. Law Econ. Organ. 1995, 11, $205-226$. [CrossRef]

4. Leonard-Barton, D. Core capabilities and core rigidities: A paradox in managing new product development. Strateg. Manag. J. 1992, 13, 111-125. [CrossRef]

5. Karamushka, O.; Moroz, S.; Vasylieva, N. Information component of innovative support for agricultural enterprises capital. Balt. J. Econ. Stud. 2018, 4, 145-150. [CrossRef]

6. Cui, H.; Shi, J. Research on the relationship between open innovation, government support and the performance of leading agriculture enterprises. Issues Agric. Econ. 2013, 34, 84-91. (In Chinese)

7. Roper, S.; Hewitt-Dundas, N. Innovation persistence: Survey and case-study evidence. Res. Policy 2008, 37, 149-162. [CrossRef]

8. Polakovič, P.; Hennyeyová, K.; Šilerová, E.; Hallová, M.; Vaněk, J. Managerial ICT education, innovation objectives and barriers to education of agricultural enterprises managers. In Agrarian Perspectives XXVII. Food Safety-Food Security, Proceedings of the 27th International Scientific Conference, Prague, Czech Republic, 19-20 September 2018; Czech University of Life Sciences Prague, Faculty of Economics and Management: Prague, Czechia, 2018; pp. 243-251.

9. Uvarova, I.; Vitola, A. Innovation challenges and opportunities in European Rural SMEs. Public Policy Adm. 2019, 18, 152-166. [CrossRef] 
10. Li, L.; Wang, L. Study on the relationship between knowledge management and business performance for agricultural businesses from the perspective of social network. Sci. Technol. Manag. Res. 2015, 35, 141-145. (In Chinese)

11. Sammarra, A.; Biggiero, L. Heterogeneity and specificity of inter-Firm knowledge flows in innovation networks. J. Manag. Stud. 2008, 45, 800-829. [CrossRef]

12. Chesbrough, H.W. The era of open innovation. Manag. Innov. Chang. 2006, 127, 34-41.

13. Verona, G.; Ravasi, D. Unbundling dynamic capabilities: An exploratory study of continuous product innovation. Ind. Corp. Chang. 2003, 12, 577-606. [CrossRef]

14. Yao, Z.; Zhang, X.; Liu, Z.; Zhang, L.; Luo, J. Narcissistic leadership and voice behavior: The role of job stress, traditionality, and trust in leaders. Chin. Manag. Stud. 2019. [CrossRef]

15. Xiang, G.; Wang, Y. Capabilities of the enterprise's sustainable innovation: Key factors and evaluation model. Chin. J. Manag. Sci. 2004, 6, 138-143. (In Chinese)

16. Antonelli, C.; Crespi, F.; Scellato, G. Inside innovation persistence: New evidence from Italian micro-data. Struct. Chang. Econ. Dyn. 2012, 23, 341-353. [CrossRef]

17. Haned, N. Firm Performance, Sources and Drivers of Innovation and Sectoral Technological Trajectories. Ph.D. Thesis, Thèse de sciences économiques, Université Lumière, Lyon, France, 2011.

18. Cyert, R.M.; March, J.G. A Behavioral Theory of the Firm; Questia: Englewood Cliffs, NJ, USA, 1963; Volume 2, pp. 169-187.

19. Rosenkopf, L.; Nerkar, A. Beyond local search: Boundary-spanning, exploration, and impact in the optical disk industry. Strateg. Manag. J. 2001, 22, 287-306. [CrossRef]

20. Xiong, W.; Feng, X.; Chen, L. Review and prospect of boundary-spanning search abroad. Foreign Econ. Manag. 2011, 33, 18-26. (In Chinese)

21. Grant, R.M. Toward a knowledge-based theory of the firm. Strateg. Manag. J. 1996, 17, 109-122. [CrossRef]

22. Katila, R.; Ahuja, G. Something Old, Something New: A Longitudinal Study of Search Behavior and New Product Introduction. Acad. Manag. J. 2002, 45, 1183-1194.

23. Bierly, P.E., III; Daly, P.S. Alternative knowledge strategies, competitive environment, and organizational performance in small manufacturing firms. Entrep. Theory Pract. 2007, 31, 493-516. [CrossRef]

24. Sidhu, J.S.; Commandeur, H.R.; Volberda, H.W. The multifaceted nature of exploration and exploitation: Value of supply, demand, and spatial search for innovation. Organ. Sci. 2007, 18, 20-38. [CrossRef]

25. Yang, X.; Gu, X.; Wang, Y. Research on the enterprise' external technology search balance: Based on the perspective of exploration and exploitation. Stud. Sci. Sci. 2015, 33, 907-914. (In Chinese)

26. Lin, C.J.; Li, C.R. The Effect of Boundary-Spanning Search on Breakthrough Innovations of New Technology Ventures. Ind. Innov. 2013, 20, 93-113. [CrossRef]

27. Huang, P. Strategic Deviance, Customer Concentration and Enterprise Value: A Case Study of Agricultural Listed Enterprises. Asian Agric. Res. 2018, 10, 33-40.

28. Wei, Y.S.; Atuahene-Gima, K. The moderating role of reward systems in the relationship between market orientation and new product performance in China. Int. J. Res. Mark. 2009, 26, 89-96. [CrossRef]

29. Kovács, K. Managerial Challenges in Hungarian Agricultural Enterprises. In Managing Agricultural Enterprises; Bryła, P., Ed.; Palgrave Macmillan: Cham, Switzerland, 2018; pp. 225-239.

30. Laursen, K. Keep searching and you'll find: What do we know about variety creation through firms' search activities for innovation? Ind. Corp. Chang. 2012, 21, 1181-1220. [CrossRef]

31. Fleming, L. Recombinant uncertainty in technological search. Manag. Sci. 2001, 47, 117-132. [CrossRef]

32. Ye, J.; Ren, H.; Hao, B. The inner mechanism of a curvilinear effect between external knowledge heterogeneity and innovation performance from the perspective of knowledge reconfiguration and absorptive capacity. Sci. Res. Manag. 2016, 37, 8-17. (In Chinese)

33. Carlile, P.R. A Pragmatic View of Knowledge and Boundaries: Boundary Objects in New Product Development. Organ. Sci. 2002, 13, 442-455. [CrossRef]

34. West, J.; Salter, A.; Vanhaverbeke, W.; Chesbrough, H. Open innovation: The next decade. Res. Policy 2014, 43, 805-811. [CrossRef]

35. Nesta, L. Knowledge and productivity in the world's largest manufacturing corporations. J. Econ. Behav. Organ. 2008, 67, 886-902. [CrossRef]

36. Chen, J.; Wu, B. The impact of openness on the acquisition of external key resources by enterprises with open innovation. Sci. Res. Manag. 2012, 33, 10-21. (In Chinese) 
37. Feng, W.; Zhang, S.; Sun, Y. Mechanism and countermeasures of improving enterprise innovation capability based on knowledge integration and sharing. Inf. Sci. 2017, 35, 50-54. (In Chinese)

38. Zhang, B.; Ren, H. An empirical study on ascending mechanism of virtual organization continuous innovation capability. Bus. Manag. J. 2018, 40, 122-139. (In Chinese)

39. Zhu, Y.; Zhou, F.; Sha, Z. A research on relationship between boundary-spanning search and business mode innovation: Perspective from absorptive capacity. Bus. Manag. J. 2016, 38, 92-104. (In Chinese)

40. Yam, R.; Lo, W.; Tang, E.P.Y.; Lau, A.K.W. Analysis of sources of innovation, technological innovation capabilities, and performance: An empirical study of Hong Kong manufacturing industries. Res. Policy 2011, 40, 391-402. [CrossRef]

41. Pertusa-Ortega, E.M.; Molina-Azorín, J.F.; Claver-Cortés, E. Competitive strategy, structure and firm performance: A comparison of the resource-based view and the contingency approach. Manag. Decis. 2010, 48, 1282-1303. [CrossRef]

42. Lee, R.P.; Chen, Q. The immediate impact of new product introductions on stock price: The role of firm resources and size. J. Prod. Innov. Manag. 2009, 26, 97-107. [CrossRef]

43. Huergo, E.; Jaumandreu, J. How does probability of innovation change with firm age? Small Bus. Econ. 2004, 22, 193-207. [CrossRef]

44. Baron, R.M.; Kenny, D.A. The moderator-mediator variable distinction in social psychological research: Conceptual, strategic, and statistical consideration. J. Personal. Soc. Psychol. 1986, 51, 1173-1182. [CrossRef]

45. Laursen, K.; Salter, A. Open for innovation: The role of openness in explaining innovation performance among U.K. manufacturing firms. Strateg. Manag. J. 2006, 27, 136-150. [CrossRef]

46. Cohen, W.M.; Levinthal, D.A. Absorptive capacity: A new perspective on learning and innovation. Adm. Sci. Q. 1990, 35, 128-152. [CrossRef]

(C) 2020 by the authors. Licensee MDPI, Basel, Switzerland. This article is an open access article distributed under the terms and conditions of the Creative Commons Attribution (CC BY) license (http://creativecommons.org/licenses/by/4.0/). 